\title{
Subglacial drumlins and englacial fractures at the surge-type glacier, Múlajökull, Iceland
}

\author{
Andrew Finlayson*1, Emrys Phillips ${ }^{1}$, Ívar Örn Benediktsson ${ }^{2}$, Lucas K. \\ Zoet $^{3}$, Neal R. Iverson ${ }^{4}$, and Jez Everest ${ }^{1}$ \\ ${ }^{1}$ British Geological Survey, The Lyell Centre, Research Avenue South, \\ Edinburgh EH14 4AP, UK \\ ${ }^{2}$ Institute of Earth Sciences, University of Iceland, Askja, Sturlugata 7, \\ IS-101 Reykjavík,Iceland \\ ${ }^{3}$ Department of Geoscience, University of Wisconsin-Madison, 1215 W \\ Dayton, Madison, WI 53706, USA \\ ${ }^{4}$ Department of Geological and Atmospheric Sciences, Iowa State \\ University, 253 Science I, 2237Osborn Drive, Ames, IA 50011, USA
}

\section{Abstract}

The interaction between drumlins and overriding glacier ice is not well studied, largely due to the difficulty of identifying and accessing suitable active subglacial environments. The surge-type glacier Múlajökull, in central Iceland, overlies a known field of actively forming drumlins and therefore provides a rare opportunity to investigate the englacial structures that have developed in association with ice flow over the subglacial drumlins. In this study detailed ground penetrating radar surveys are combined with field observations to identify clear sets of up-glacier and down-glacier dipping fractures at Múlajökull's margin. These are interpreted as conjugate shear planes or P- and R-type Reidel shears that developed and filled with saturated sediment derived from the glacier bed, during a previous surge. The fracture sets exhibit focused spatial distributions that are influenced by the subglacial topography. In particular, down-glacier dipping fractures are strongly focused over drumlin stoss slopes. These fractures, although well developed at depth, were mostly unable to 


\begin{abstract}
transmit basal water and sediment up to the glacier surface during the surge cycle. In contrast, up-glacier dipping fractures formed over drumlin lee sides and in more gently sloping swales, and more frequently connected to the glacier surface providing a pathway for the evacuation of basal water and water-saturated sediment. The study suggests that the subglacial drumlins under Múlajökull's margin has influenced the nature and distribution of englacial fractures, which could potentially contribute to spatial variations in basal water pressure during a surge.
\end{abstract}

\title{
1 Introduction
}

Drumlins are abundant across landscapes that were submerged beneath the former Laurentide, Fennoscandian, and British-Irish ice-sheets (e.g. Aylsworth \& Shilts 1989, Kleman et al. 1997, Clark \& Meehan 2001, Hughes et al. 2010). Geophysical surveys from the contemporary West Antarctic Ice Sheet have also identified features that appear to be small drumlins (Smith et al. 2007) and other streamlined subglacial bedforms (King et al. 2009, Bingham et al. 2017) at the active ice-bed interface. A substantial volume of research has focused on the characteristics of deglaciated drumlins in order to develop hypotheses for the genesis and evolution of these landforms (Rose 1987, Boyce \& Eyles 1991, Stokes \& Clark 2002, Clark et al. 2009, Stokes et al. 2011, Spagnolo et al. 2012, Hooke \& Medford 2013, Eyles et al. 2016). However, less attention has been given to the potentially important effects that drumlins have on the overriding ice, and field studies that investigate the interaction between drumlins and glacier ice are extremely rare. The current gap in research is largely due to the lack of opportunities to investigate ice flowing over a known field of subglacial drumlins.

Johnson et al. (2010) have described a field of small drumlins at Múlajökull (Fig. 1), a surge-type glacier in central Iceland, as 'active' because the drumlins are shaped by the current glacier regime. The suggestion by these authors, that the exposed drumlins are part of a field that extends under the glacier, has recently been confirmed by a ground 
penetrating radar (GPR) survey, which identified five drumlins under the marginal zone of Múlajökull (Lamsters et al. 2016). Múlajökull therefore provides a rare opportunity to examine drumlins in combination with englacial structures that have developed in the overriding ice.

Englacial structures, such as fractures and faults, provide an indication of the stress and strain rate in ice, and so can provide insights into glacier dynamics (Moore et al. 2010, Murray \& Booth 2010, Phillips et al. 2013, 2014, Lovell et al. 2015). These structures have also been suggested to play an important role in glacier drainage (Fountain et al. 2005, Harper et al. 2010), and have been linked to dewatering and the evacuation of water-saturated sediment from the bed during glacier surges (Bennett et al. 2000, Woodward et al. 2003, Rea \& Evans 2011). Englacial fractures are often marked by variations in water, sediment, or air content that produce dielectric contrasts and reflect GPR waves (Arcone et al. 1995, Woodward \& Burke 2007). As a result GPR provides a valuable tool to map these structures, particularly when interpretations can be supported by observations of exposed structures on the ice surface or in ice cliffs (Murray et al. 1997, Woodward et al. 2003, Phillips et al. 2013). The research described here uses GPR, combined with glacier surface observations, to identify englacial structures that relate to ice flow over the subglacial drumlin field at Múlajökull. Different sets of fractures are identified, and their nature and spatial distribution in relation to the glacier bed topography are described. The findings are used to test whether subglacial drumlins might influence the characteristics and spatial distribution of overlying englacial fractures, with potential implications for the evacuation of water and water-saturated sediment from the bed during a surge cycle. 


\section{Setting}

8 Múlajökull is a surge-type outlet glacier of the warm-based Hofsjökull ice cap $\left(800 \mathrm{~km}^{2}\right)$ 69 in central Iceland (Fig. 1). The glacier descends from the central icecap to flow through 70 a 2-km-wide valley, between the Hjartafell and Kerfjall mountains, before spreading out 71 as an $8 \mathrm{~km}^{2}$ piedmont lobe onto a drumlinized foreland. The sediment in the foreland is 72 primarily composed of a diamicton with a silt and sand dominated matrix (McCracken 73 et al. 2016). There is no bedrock exposed on the foreland and the nearest outcrops are 74 seen at the steep flanks of Hjartafell and Kerfjall mountains (Fig. 1).

75

Landforms typical of surge-type glaciers, such as crevasse-squeeze ridges and flutes are present across the foreland and are superimposed on the exposed drumlins (Jónsson et al. 2014). Glaciotectonic moraines are also present and mark the terminal positions of previous surges, which on average have occurred every 10-20 years (Björnsson et al. 2003). The two most recent surges were in 1992 and in 2008 when the glacier advanced beyond the current margin by $\leq 800 \mathrm{~m}$ and $\leq 200 \mathrm{~m}$, respectively (Benediktsson et al. 2015, Jónsson et al. 2014).

Benediktsson et al. (2016) have mapped a total of 143 drumlins in the foreland of Múlajökull. Inside the 1992 surge moraine (which was also occupied during the earlier 1954, 1972, and 1986 surges) the drumlins exhibit a mean length of $230 \mathrm{~m}$, a mean width of $81 \mathrm{~m}$, and a mean relief of $7.8 \mathrm{~m}$. Beyond the moraine, the drumlins exhibit a mean length of $169 \mathrm{~m}$, a mean width of $94 \mathrm{~m}$, and a mean relief of $7.5 \mathrm{~m}$. These characteristics place the exposed Múlajökull drumlins below the 10th percentile for drumlin lengths and widths globally (Ely et al. 2016). However, their spatial dimensions do fall within the ranges for landforms that have been included in other drumlin datasets (Clark et al. 2009, Hillier et al. 2018), and the relief of the exposed Múlajökull drumlins is consistent with average values from other glaciated landscapes (Spagnolo et al. 2012). Lamsters 
et al. (2016) have also examined the morphology of five subglacial drumlins interpolated from GPR profiles at Múlajökull. They found that these landforms were larger then the exposed drumlins, reaching lengths of up to $420 \mathrm{~m}$ and heights of almost $20 \mathrm{~m}$.

The margin of Múlajökull lies at approximately $600 \mathrm{~m}$ above sea level, although the ice bed under the centre of the piedmont lobe is over-deepened and lies approximately $100 \mathrm{~m}$ lower (Björnsson 1988). Much of the glacier surface is relatively level $\left(1-3^{\circ}\right)$, except near the margin where the slope steepens to $10-12^{\circ}$ (Johnson et al. 2010). The central margin of Múlajökull is dominated by a radial pattern of 50-200-m-long longitudinal, splaying crevasses, which tend to be focused over the tops or at the heads of emergent drumlins (Benediktsson et al. 2016). The distribution of these longitudinal surface crevasses has been described previously and tentatively linked to the evolution of proto-drumlins (Johnson et al. 2010, Benediktsson et al. 2016). However, there has not yet been any description of englacial structures relating to the down-glacier flow of ice over the submerged drumlin field.

\section{Methods}

Ground penetrating radar surveys were used to investigate glacier bed topography and internal ice structures in two survey areas at the central and northern margin of Múlajökull (Fig. 2A,B). The northern margin survey area partially overlaps with the area surveyed by Lamsters et al. (2016). A PulseEKKO Pro system with $100 \mathrm{MHz}$ antennae was towed manually across the glacier surface, capturing a total of $16 \mathrm{~km}$ of survey lines (Fig. 2A). An odometer wheel was used to trigger data collection at $0.25 \mathrm{~m}$ intervals, and each trace was stacked 16 times to increase signal-to-noise ratio. During the surveys, antennae were aligned perpendicular to the travel direction. Positional data were stored alongside every 5th GPR trace, and captured using a standalone Novatel SMART-V1 GPS antenna. 
GPR data from the glacier were processed using a dewow filter, 2-D migration, average background subtraction, SEC (spreading and exponential compensation) gain, and topographic correction. A radar wave velocity of $0.16 \mathrm{~m} \mathrm{~ns}^{-1}$ was used for depth conversion of the GPR data (Sensors \& Software 2003).

Thirty-two survey lines were directed parallel to glacier flow, and twelve lines were directed perpendicular to glacier flow. Line spacing varied from $15 \mathrm{~m}$ to $200 \mathrm{~m}$ (Fig. $2 \mathrm{~A}, \mathrm{~B})$; the presence of moulins and crevasses prevented the collection of regular grids of more closely-spaced survey lines. Both the ice-flow parallel and transverse profiles were used to map the bed topography. The glacier bed was picked manually along the GPR profiles. These picks were then used to generate bed interpolations for the central and northern margin zones by performing a discrete smooth interpolation (Mallet, 2002) in the Paradigm GOCAD ${ }^{\circledR}$ software program. In addition, dipping reflector surfaces that are aligned broadly perpendicular to the ice flow direction were picked from the ice-flow parallel survey lines. These internal reflectors were picked and digitised at $2 \mathrm{~m}$ horizontal increments along the paths of the profiles, and were projected over the interpolated glacier bed topography. The utilised characteristics of the reflectors included: length, depth (which was normalised to account for local ice thickness), apparent dip (because it cannot be established if the GPR profiles are parallel to the true dip direction of the reflecting surface), and spatial position relative to the subglacial topography.

Observations of structures on the glacier surface and in the walls of two longitudinal crevasses were made at the same time as the GPR surveys, in order to aid the interpretation of englacial reflectors identified in the radar data. The orientation (dip and dip azimuth) of surface structures were measured using a compass clinometer and plotted on a lower hemisphere stereographic projection. Indicators for sense of movement along fractures, such as offsets or associated folds, were also recorded where they were evident. In addition, a high resolution digital elevation model for part of the central margin was 
generated from a UAV (unmanned aerial vehicle) survey, and used to identify surface structures in the vicinity of selected radar profiles.

\section{Bed topography at glacier margin}

Near-continuous, high-amplitude, basal reflectors were clearly observed in the GPR profiles (Figs. 2C,D). These reflectors could be traced to the exposed glacier bed at the ice margin, clearly indicating that they represent the bed topography. Figures $2 \mathrm{~A}$ and $2 \mathrm{~B}$ show the position of survey lines and the ice thickness determined from GPR. Interpolated bed topography maps for the central and northern margin sites are shown in Figure 3.

At the central margin, the subglacial stoss sides of four partially exposed drumlins with intervening swales can be clearly identified (Fig. 3A). In plan form the drumlins possess spindle and parabolic shapes. Subglacially, the vertical relief between swales and drumlin crests is approximately $20 \mathrm{~m}$, which is greater than the relief of the exposed drumlins in the foreland (Benediktsson et al. 2016). The transverse distance between crests ranges from $200-250 \mathrm{~m}$, which is similar to the spacing between the exposed drumlins mapped by Benediktsson et al. (2016), and to the crest spacing characteristics of many drumlins elsewhere (Clark et al. 2018). The stoss slopes of the four subglacial drumlins are between 70 and $140 \mathrm{~m}$ long, and range in angle between $5^{\circ}$ and $20^{\circ}$. The bases of the swales are more gently inclined and have up-glacier and down-glacier facing slopes that generally range from $<10^{\circ}$ to subhorizontal. These swales are linked in the up-glacier and down-glacier direction through linear topographic depressions between the drumlins (e.g. Fig 3A). In addition to the streamlined bedforms, part of a possible drumlinised transverse ridge is also visible. 
Two large drumlins are revealed in full under the area surveyed at the northern margin (Fig. 3B). Part of a third drumlin is also visible at the southern edge of this area, and two smaller bedforms can be identified further north. These bedforms, particularly in the south, appear to occupy a larger transverse ridge located down-glacier from a subglacial overdeepening, resulting in extended stoss slopes (up to $300 \mathrm{~m}$ long and up to $40 \mathrm{~m}$ in relief). This ridge in front of the overdeepening was also reported by Lamsters et al. (2016), and was suggested to be the edge of the main overdeepening that is present under Múlajökull (Björnsson 1988). The stoss slopes range in angle between $5^{\circ}$ and $15^{\circ}$, and the lee slopes are shallower (between $3^{\circ}$ and $7^{\circ}$ ). The transverse distance between bedform crests is $150-250 \mathrm{~m}$, and is similar to the subglacial drumlins under the central margin and to the exposed drumlins in the foreland. The vertical relief between the crests and the intervening swales is $10-15 \mathrm{~m}$, which like the central margin, exceeds the relief of many of the exposed drumlins in Múlajökull's foreland. The survey area at the northern margin partially overlaps with the area investigated by Lamsters et al. (2016), and the bed topography described here supports their results.

At both sites, the subglacial bedforms lack clear breaks in slope at their margins, and instead show a smooth transition between the swales in both the longitudinal and the transverse directions (Figs. 2C,D, 3). This bedform morphology is consistent with the suggestion that subglacial drumlins tend towards waveforms rather than 'blister-onthe-landscape' morphology (Spagnolo et al. 2012). The subglacial drumlin morphology contrasts to many of the exposed drumlins in the foreland, where apparent sharp boundaries are likely to have been created by lakes and sediments partially infilling the swales (e.g. Finlayson 2013, Benediktsson et al. 2016). Indeed, lake formation and sedimentation following drumlin emergence would explain the observed difference in relief between the subglacial drumlins and the exposed drumlins, which has been reported here and by Lamsters et al. (2016). It would also explain why these subglacial drumlins have a relatively high relief compared to a global dataset of exposed drumlins (Spagnolo et al. 


\section{$5 \quad$ Englacial structures}

The unmigrated transverse profiles show numerous near-surface and englacial hyperbolas, representing surface features (e.g. shallow water-filled fractures) and englacial features (Fig. 4A). Lamsters et al. (2016) have also described these englacial hyperbolas in transverse GPR profiles at Múlajökull's margin, interpreting them as reflections from englacial channels. In addition to these isolated channel-like features, strong subhorizontal englacial reflectors have been identified in this study, within the migrated transverse profiles (Fig. 4B). A number of these reflectors were observed to join with dipping reflectors in the intersecting ice-flow parallel profiles, indicating that they represent parts of planar englacial structures (e.g. Fig. 4C).

These dipping planar surfaces, with trends broadly normal to the ice-flow direction, were the focus of investigation in the ice-flow parallel survey lines. Clear sets of up-glacier dipping (Fig. 4D) and down-glacier dipping (Fig. 4E) reflectors were identified in both of the areas of mapped bed topography. The characteristics and spatial distributions of these features reflectors, and their relation to the glacier bed topography, are described below and are presented in Figures 5 and 6 .

\section{$5.1 \quad$ Up-glacier dipping reflectors}

One-hundred-and-five up-glacier dipping reflectors were identified from longitudinal profiles in the central marginal zone (Fig 5A), and 34 were identified from profiles in the northern margin (Fig. 5D). In both areas the up-glacier dipping reflectors have a bimodal depth distribution with a large cluster focused in the upper 10-50\% of local ice-depth and a smaller group near the bed at $80-100 \%$ of local ice depth (Figs 6A,D). In the central mar- 
gin the up-glacier dipping reflectors have a median apparent dip angle of $22^{\circ}$ with a slight skew towards shallower angles (Fig. 6C). The median apparent dip is slightly shallower in the northern margin $\left(18^{\circ}\right)$, and is more skewed towards shallow angles. The median horizontal flow-parallel distances over which the up-glacier dipping reflectors were traced at the central and northern margin, are $6 \mathrm{~m}$ and $10 \mathrm{~m}$ respectively (Table 1 ). The longest up-glacier dipping reflector was traced over a horizontal flow-parallel distance of $24 \mathrm{~m}$ in the northern margin. In the central glacier margin the up-glacier dipping reflectors occur over a range of bed slopes (Fig. 5B). The proportion of up-glacier dipping reflectors that occur over both stoss and down-glacier facing bedslopes mirrors the overall slope of the bed, and suggests these features have no preferential spatial distribution (Figure 7A). Up-glacier dipping reflectors also occur over varying bedslopes at the northern margin (Fig. 5D); however, the proportion that was detected over down-glacier facing bedslopes is slightly more than would be expected if the features were uniformly distributed over all bedslopes in the area (Fig. 7B).

\subsection{Down-glacier dipping reflectors}

Fifty-two down-ice dipping reflectors were identified in the profiles from the central margin survey zone (Fig 5A), and 40 were identified at the northern margin (Fig. 5D). The down-ice dipping reflectors in both areas are focused closer to the bed, with peak distributions between $50 \%$ and $90 \%$ of the local ice depth (Fig 6B,E). They are normally distributed around a mean apparent dip of $23^{\circ}$ at the central margin, and $29^{\circ}$ at the northern margin (Fig. 6C,F). The down-glacier dipping reflectors were traced over median horizontal flow-parallel distances of $14 \mathrm{~m}$ and $20 \mathrm{~m}$ at the central and northern sites, respectively (Table 1). The longest down-glacier dipping reflector was traced over a horizontal flow-parallel distance of $68 \mathrm{~m}$. At both sites the down-glacier dipping reflectors are strongly focused over adverse bedslopes, with $75 \%$ of the reflectors occurring over the stoss sides of drumlins in the central margin, and $85 \%$ occurring over the stoss slopes of 
drumlins in the northern margin (Figs. 5C,F and 7). At both locations the proportion of down-glacier dipping reflectors that occur over stoss slopes is much higher than would be expected if the reflectors were uniformly distributed over all bedslopes in the area (Fig. 7).

\subsection{Surface observations linked to the reflectors}

\subsubsection{Up-glacier dipping reflectors and surface structures}

Observational data from the glacier surface at the central margin were combined with the GPR results to aid the interpretation of the reflectors (Figs 8, 9, 10). Many up-glacier dipping reflectors could be traced to the glacier surface where they intersect laterally extensive sediment-filled surface fractures that were observed on the ground and in the UAV imagery (Figs. 8A,9A). Surface measurements from these sediment-filled fractures show that their dips (Fig. 8D) are broadly consistent with the apparent dips of the up-glacier dipping reflectors that were identified in the GPR profiles. Vertical sections in the walls of longitudinal crevasses also revealed up-ice dipping fractures that are similar in orientation to the reflectors, suggesting that a fracture interpretation is appropriate (Figs. 8B,10). In one crevasse section, the ice foliation formed an inclined anticline that appeared to have been truncated and offset by an up-ice dipping fracture (Figs. 10A,B). The apparent offset may be a result of thrusting along the fracture plane or shear displacement during opening and closing of the fracture (Hudleston 2015). Most other fractures revealed little evidence of clear offsets along the fracture planes.

In several places, up-glacier dipping fracture planes could be traced from the glacier bed to the ice surface, where ridges of frozen sands and fine gravel were observed (e.g. Figs. 8A,9B). The sands show evidence of sorting and grading indicating that they had been deposited by flowing water, and suggesting that pressurised water had previously exploited these up-glacier dipping fractures. The timing of the sediment emplacement is 
not known, though it may have occurred during a phase of extension and relaxation along the fractures during or immediately after the termination of a surge (e.g. Woodward et al. 2003). However, the frozen nature of the sediment and observations of sediment deformation, such as isoclinal folds, demonstrates that more recent processes have involved compression of fracture walls (Fig. 8C.).

\subsubsection{Down-glacier dipping reflectors and surface structures}

Down-glacier dipping reflectors in the longitudinal GPR profiles appear, in places, to intersect horizontal reflectors in transverse profiles, suggesting that these features also represent fracture planes with surface trends that are approximately normal to ice flow (Fig. 4C). Observations of down-glacier dipping fractures were rare on the glacier surface (Fig. 8D) and in the upper parts of the longitudinal crevasse walls (Fig. 10). This observation is consistent with the less frequent detection of down-glacier dipping fractures close to the ice surface in the GPR profiles (Fig. 6B,E). Where down-ice dipping fractures were observed in crevasses, there was either no clear offset at the surface, or small (0-10 $\mathrm{cm}$ ) extensional offsets across the foliation.

Approximately one kilometre to the west of the central margin area, an episode of high water discharge was observed at several points along a $\sim 5$-m-long surface fracture that linked to a down-glacier dipping reflector connecting with the glacier bed (Fig. 11B). Although the event was temporary, it demonstrates the potential of these down-glacier dipping fractures to connect with pressurised water at the bed. 


\section{Discussion}

\subsection{Origin of the fracture sets}

Previous studies using GPR on surge-type glaciers have described up-glacier dipping englacial fractures as re-orientated basal crevasse fills where dilated sediments have been squeezed into basal crevasses (Woodward et al. 2003), or as sediment-filled thrusts (Murray et al. 1997, Murray \& Booth 2010). Observations of up-glacier dipping fractures on glacier surfaces and in cliff faces have resulted in similar interpretations (Lawson et al. 1994, Hambrey et al. 1996, Bennett et al. 2000, Woodward et al. 2002), although the conditions required for thrust faulting in glaciers have been questioned (Moore et al. 2010, Hudleston 2015). There are few descriptions of down-glacier dipping fractures from previous glacier GPR work. Phillips et al. (2013, 2014) interpreted a down-glacier dipping GPR reflector at the margin of the non-surging glacier, Falljökull in south-east Iceland, as a normal fault. At that location the fault was associated with a notable (metre-scale) surface displacement that showed continued development over time (Phillips et al. 2014). In other surging glaciers, rare down-glacier dipping fractures that were observed in ice cliff sections have been interpreted as backthrusts, associated with intense longitudinal compression and shortening (Lawson et al. 1994, Bennett et al. 2000).

At Múlajökull, both down-glacier dipping and up-glacier dipping fractures are common features, and their apparent dip angles are focused between 20-30 ${ }^{\circ}$ (Figs. 5,6). The initial development of these up-glacier and down-glacier dipping fracture sets would have required strain rates that were sufficient to cause brittle failure of the ice. Such strain rates are far more likely to be achieved during surging than during quiescent flow (Moore et al. 2010). We suggest two possible mechanisms below that could explain the initial formation of these fracture sets during a previous surge of Múlajökull.

First, the fractures may have initiated as conjugate shear planes during the rapid 
longitudinal compression that is associated with an advancing surge front (e.g. Sharp et al. 1988). Under surge conditions close to the glacier margin, the maximum principal stress would be approximately parallel to glacier flow, and the minimum principal stress would be vertical due to the thin ice. Using the Coulomb failure criteria, conjugate planes of shear failure would be expected to form at an angle $\beta$ to the maximum principal stress, given by

$$
\beta=45^{\circ}-(\phi / 2),
$$

where $\phi=\tan ^{-1} \mu$, and $\mu$ is the internal friction coefficient (Jaeger et al. 2007). Using 0.5 as the internal friction coefficient for ice (Jaeger et al. 2007, Schulson 2001) gives a value for $\beta$ of $31.7^{\circ}$, which is close the median measured apparent dips $\left(20-30^{\circ}\right)$ for the up-ice and down-ice dipping fracture sets (Figs. 6C,F).

Alternatively the up-glacier dipping and down-glacier dipping fracture sets may have developed as compressional P-type and extensional R-type Riedel shears, respectively, during accelerated strain under simple shear. In simple shear, failure surfaces would be expected to develop initially at an angle of $\phi / 2$ to general direction of movement (Tchalenko 1968). Using $\mu=0.5$ gives a predicted Riedel shear angle of $13.3^{\circ}$, which is lower than the median apparent fracture angles measured in this study. However, the up-glacier dipping fracture populations do exhibit a skew towards lower angles (Figs. $6 \mathrm{C}, \mathrm{F})$, suggesting that this mechanism could also account for a number of the fractures. In addition, the slight asymmetry of the up-glacier and down-glacier dipping fracture sets at the northern margin suggests that a component of rotation and simple shear has occurred since fracture initiation (Fig. 6F).

The up-glacier dipping and down-glacier dipping fracture sets at Múlajökull could have initiated through either of the processes described above, or by some combination 
of the two. Both fracture types have been described at other glaciers. Conjugate shears are linked with fracture patterns and crevasse squeeze ridge networks in front of some surge-type glaciers (Rea \& Evans 2011). Riedel shears have been identified on glacier surfaces along strike-slip marginal shear zones (Phillips et al. 2017), and have also been exposed in ice walls during tunnel excavations (Fitzsimons \& Sirota 2002). For both scenarios, the high water pressures that characterise surging would have helped form the fractures at Múlajökull. As the surge front then passed through, causing the ice margin to advance, longitudinal extension would have become more dominant (e.g. Sharp et al. 1988, Lawson et al. 1994), allowing these up-ice and down-ice dipping fractures to open and facilitate the injection of pressurised water and sediment (Woodward et al. 2002, 2003), which in places reached the ice surface (e.g. Fig. 8).

\subsection{Fractures and the glacier bed at Múlajökull}

While the mechanisms discussed above could account for the general occurrence of the sets of up-glacier dipping and down-glacier dipping fractures at the margin of Múlajökull, they cannot fully explain the observed spatial distributions of these features. Specifically, an explanation is required for the following observations: (i) the down-glacier dipping fractures are clustered over the stoss sides of drumlins (Figs. 5,7), are distributed at depths closer to glacier bed (Fig. 6B,E) and are generally longer than the up-glacier dipping fractures (Table 1); and (ii) the up-glacier dipping fractures occur over a wider range of bed slopes (with a relatively higher proportion occurring over down-glacier facing slopes at the northern margin)(Figs. 5,6) and are focused at shallow depths with smaller populations close to the bed (Fig. 6A,D).

During a surge the fracture sets form either as conjugate shear planes or as P- and Rtype Reidel shears, as described above. We assume that there is no initial spatial preference for the fracture distributions and that potential fracture planes can occur uniformly 
throughout the ice margin. However, the undulating nature of the subglacial topography makes down-glacier dipping fracture planes be more likely to intersect the bed at a high angle on the stoss side of drumlins (Fig. 12). Conversely, the up-glacier dipping fractures, which have a median up-glacier dip angle of $\sim 20^{\circ}$ (Fig. $6 \mathrm{C}, \mathrm{F}$ ), are orientated almost sub-parallel to the subglacial drumlin stoss slopes (which may be up to $20^{\circ}$ ). As a result, the up-glacier dipping fractures are less likely to intersect drumlins stoss sides and should preferentially intersect the bed over lee slopes and in the swales.

Where a fracture plane does connect to the glacier bed, the high basal water pressures that accompany glacier surging will help to open the fracture (Rea \& Evans 2011). Modelling by Iken (1981) indicates that ice will accelerate across a stoss surface as it moves towards the crest of a subglacial bump. Therefore, over the stoss slopes of the drumlins the down-ice sides of down-glacier dipping fractures will move faster than the up-ice sides, promoting fracture opening. Although the mean compressive stresses will act to close the fractures, these will be reduced by the high water pressures that accompanied the surge, enabling the bed-parallel deviatoric stress to remain tensile. Under these conditions, saturated basal sediment can be injected from the bed into the down-glacier dipping fractures. This sediment helps generate the strong reflections that are now seen in the GPR profiles (e.g. Fig. 4D).

The down-glacier dipping fractures that are injected with pressurised water and saturated basal sediment will be able to extend in the up-glacier direction towards thicker ice. Due to their direction of propagation, these down-glacier dipping fractures are less likely to breach the glacier surface to discharge water and sediment (Fig. 6B,E, 12). This effect could help sustain higher water pressures on the stoss sides of drumlins than in zones where fractures at the bed intersect the glacier surface.

Up-glacier dipping fractures could occur at the bed over some stoss slopes, but they 
are more likely to intersect the bed on lee slopes and in the more gently dipping interdrumlin swales (Figs. 5B,E, 12). Where pressurised water and sediment is injected from the bed into up-glacier dipping fractures, it will move in the down-glacier direction towards thinner ice. Some fractures will not extend to the glacier surface (Fig. 6A,D). However, others will breach the surface of the thinner ice, forming a pathway to evacuate water and sediment from the bed during a surge (Figs.8,9,12). This effect may contribute to basal water pressures being lower in these zones than on the drumlin stoss sides. Such variations could contribute to the pattern of effective stresses at the bed during a glacier surge. Indeed, previous work at this site has invoked higher effective stresses between drumlins, although in those studies the stress patterns have been related to the quiescent phase (Benediktsson et al. 2016, McCracken et al. 2016, Iverson et al. 2017).

An additional source for the more widespread occurrence of shallow up-glacier dipping fractures could also come from reorientated traces of surface crevasses. These features can form pre-existing planes of weakness, some of which will be close to the optimum angle for renewed fracture development (and potentially thrusting) at shallow depths during a surge (Moore et al. 2010). Lower cryostatic pressures close to the ice surface also means that the shallow up-glacier dipping fractures are more likely to remain open longer, and may be subjected to water flow or filled with surface debris. As a result, they contribute to the focused populations of up-ice dipping fractures that are preferentially observed at shallow depths (Figs. 6A,D). This focused shallow distribution makes parts of the up-glacier dipping fracture set susceptible to removal by glacier surface lowering; and this effect could partially account for their apparently shorter flow-parallel lengths (Table 1).

The discussion above relates the distributions of fractures, which were likely to have formed during the 2008 surge of Múlajökull, to the glacier bed topography (Fig. 12). A potential difficulty in this interpretation is that in the seven years between the glacier 
surge and the field survey (undertaken in July 2015) the fractures will have moved, and their position in relation to the bed could have changed. Repeat surveys of ice movement at the margin indicate ice surface speeds of $\sim 7-15 \mathrm{~m} / \mathrm{a}$ during the current period of quiescent flow (Iverson et al. 2017). Therefore the potential movement of the englacial fractures could be up to $\sim 50-100 \mathrm{~m}$. These maximum distances represent 20-40\% of the mean exposed drumlin lengths measured by Benediktsson et al. (2016) and 10-20\% of the maximum subglacial drumlin lengths reported by Lamsters et al. (2016). We suggest that these distances are not sufficient to have changed the overall relationships observed at the time of this study (Figs. 5,7). However, a proportion of fractures are likely to now be positioned over a different bedslope. For example, some of the mapped down-glacier dipping fractures in Figure 12B appear to have moved onto the crest and towards the lee side of a subglacial drumlin. This effect means that the patterns observed in this study may be partially masked, and there is a possibility that a stronger relationship between the fracture sets and bed topography would have been observed closer to the time of the surge.

\section{Conclusions}

GPR surveys and structural observations at the margin of Múlajökull were carried out to examine the topography of glacier bed and its relation with englacial structures in the overriding ice. The mapped bed topography supports previous work that identified drumlins under Múlajökull's margin (Lamsters et al. 2016). These small suglacial drumlins exhibit similar morphological characteristics to exposed populations on the glacier foreland and are within the size range of drumlins mapped elsewhere (Benediktsson et al. 2016, Clark et al. 2009). However, the subglacial drumlins at Múlajökull appear to be of higher relief than the exposed drumlins on the foreland. This may, in part, be because the subglacial swales have not yet been subjected to postglacial sedimentation or lake infilling. 
The GPR surveys, in combination with field observations, have revealed sets of up-ice dipping and down-ice dipping fractures within the ice that flows over the subglacial drumlins. The fracture sets are interpreted as conjugate shears or R-type and P-type Riedel shears that developed under high rates of strain during glacier surging, and were filled with saturated sediment during the surge. The detected fracture sets exhibit focussed spatial distributions. In particular, down-glacier dipping fractures are clustered over the stoss sides of drumlins, are focused at depths closer to glacier bed, and are generally longer than the up-glacier dipping fractures. The up-glacier dipping fractures occur over a wider range of bed slopes, and are focused at shallow depths with smaller populations close to the bed. We suggest that the geometric relationship between the fracture sets and the drumlin topography influences the positions where the different fractures connect to the bed, and therefore also where the transmission of basal water and sediment into these fractures can take place during a surge.

Relationships between englacial fractures and subglacial drumlins or bumps have not been described previously, and whether these have a feedback that contributes to drumlin development at Múlajökull is difficult to assess. Of potential importance is that the downglacier dipping fractures, which preferentially intersect the bed on drumlin stoss slopes, are less likely to propagate to the glacier surface to allow dewatering and discharge of saturated sediment. In contrast, the up-glacier dipping fractures, which may be expected to intersect the bed more frequently over lee slopes and swales, will more easily breach the surface enabling drainage of basal water and saturated sediment. The distribution of fracture types that develop over different parts of the drumlinised bed could, therefore, contribute to variations in local basal water pressures and effective stresses near the ice margin during surging. 


\section{${ }_{490} 8$ Acknowledgements}

500

We thank Jacob Woodard, Christian Larson, Magnús Freyr Sigurkarlsson, Eyjólfur Magnússon, and Claus Thomsen for their good company and assistance in the field. Maarten Krabbendam is thanked for helpful discussions and comments on an earlier draft of this paper. Roger LeB. Hooke and Matteo Spagnolo are thanked for their constructive reviews which helped improve the paper significantly. This work was supported by: the BGSNERC Iceland Glacier Observatory Project; the Energy Research Fund of Landsvirkjun, Iceland; the Royal Physiographic Society in Lund, Sweden; and a grant awarded to NRI from the U.S. National Science Foundation (EAR-1225812). AF, EP, and JE publish with permission of the Executive Director of the British Geological Survey. 


\section{References}

Arcone, S. A., Lawson, D. E. \& Delaney, A. J. (1995), 'Shortpulse radar wavelet recovery and resolution of dielectric contrasts within englacial and basal ice of Matanuska Glacier, Alaska, U.S.A.', Journal of Glaciology 41(137), 68 - 86.

Aylsworth, J. \& Shilts, W. (1989), 'Bedforms of the Keewatin Ice Sheet, Canada', Sedimentary Geology 62(2), 407 - 428.

Benediktsson, Í. Ö., Jónsson, S. A., Schomacker, A., Johnson, M. D., Ingólfsson, Ó., Zoet, L., Iverson, N. R. \& Stötter, J. (2016), 'Progressive formation of modern drumlins at Múlajökull, Iceland: stratigraphical and morphological evidence', Boreas 45, 567 - 583.

Benediktsson, Í. Ö., Schomacker, A., Johnson, M. D., Geiger, A. J., Ingólfsson, Ó. \& Guðmundsdötter, E. R. (2015), 'Architecture and structural evolution of an early Little Ice Age terminal moraine at the surge-type glacier Múlajökull, Iceland', Journal of Geophysical Research: Earth Surface 120, 1895 - 1910.

Bennett, M. R., Huddart, D. \& Waller, R. I. (2000), 'Glaciofluvial crevasse and conduit fills as indicators of supraglacial dewatering during a surge, Skeiðarárjökull, Iceland', Journal of Glaciology 46(152), 25-34.

Bingham, R. G., Vaughan, D. G., King, E. C., Davies, D., Cornford, S. L., Smith, A. M., Arthern, R. J., Brisbourne, A. M., De Rydt, J., Graham, A. G. C., Spagnolo, M., March, O. J. \& Shean, D. E. (2017), 'Diverse landscapes beneath Pine Island Glacier influence ice flow', Nature Communications 8, 1618.

Björnsson, H. (1988), Hofsjökull: Subglacial bedrock surface, 1:200 000, Science Institute, University of Iceland.

Björnsson, H., Pálsson, F., Sigurðsson, O. \& Flowers, G. (2003), 'Surges of glaciers in Iceland', Annals of Glaciology 36, 82-90. 
Boyce, J. I. \& Eyles, N. (1991), 'Drumlins carved by deforming till streams below the Laurentide Ice Sheet', Geology 19, 787-790.

Clark, C. D., Ely, J. C., Spagnolo, M., Hahn, U., Hughes, A. L. C. \& Stokes, C. R. (2018), 'Spatial organisation of drumlins', Earth Surface Processes and Landforms 43, 499-513.

Clark, C. D., Hughes, A. L., Greenwood, S. L., Spagnolo, M. \& Ng, F. S. (2009), 'Size and shape characteristics of drumlins, derived from a large sample, and associated scaling laws', Quaternary Science Reviews 28, 677-692.

Clark, C. D. \& Meehan, R. T. (2001), 'Subglacial bedform geomorphology of the Irish Ice Sheet reveals major configuration changes during growth and decay', Journal of Quaternary Science 16, 483-496.

Ely, J., Clark, C. D., Spagnolo, M., Stokes, C. R., Greenwood, S. L., Hughes, A. L. C., Dunlop, P. \& Hess, D. (2016), 'Do subglacial bedforms comprise a size and shape continuum?', Geomorphology 257, 108-119.

Eyles, N., Putkinen, N., Sookhan, S. \& Arbelaez-Moreno, L. (2016), 'Erosional origin of drumlins and megaridges', Sedimentary Geology 338, 2-23.

Finlayson, A. (2013), 'Digital surface models are not always representative of former glacier beds: palaeoglaciological and geomorphological implications', Geomorphology 194, 239-247.

Fitzsimons, S. \& Sirota, P. (2002), Deformation structures in cold basal ice: insights into subglacial processes, in 'Proceedings of the 16th IAHR International Symposium on Ice', Dunedin, New Zealand.

Fountain, A. G., Jacobel, R. W., Schlichting, R. \& Jansson, P. (2005), 'Fractures as the main pathways of water flow in temperate glaciers', Nature 433, $618-621$. 
Hambrey, M. J., Dowdesell, J. A., Murray, T. \& Porter, P. R. (1996), 'Thrusting and debris entrainment in a surging glacier: Bakaninbreen, Svalbard', Annals of Glaciology $22,241-248$.

Harper, J. T., Bradford, J., Humphrey, N. F. \& Meierbachtol, T. (2010), 'Vertical extension of the subglacial drainage system into basal crevasses', Nature 467, 579-582.

Hillier, J. K., Benediktsson, I. Ö., Dowling, T. P. F. \& Schomacker, A. (2018), 'Production and preservation of the smallest drumlins', GFF in press.

Hooke, R. L. \& Medford, A. (2013), 'Are drumlins a product of a thermo-mechanical instability?', Quaternary Research 79, 458-464.

Hudleston, P. J. (2015), 'Structures and fabrics in glacial ice: A review', Journal of Structural Geology 81, 1-27.

Hughes, A., Clark, C. \& Jordan, C. (2010), 'Subglacial bedforms of the last British Ice Sheet', Journal of Maps 6(1), 543-563.

Iken, A. (1981), 'The effect of the subglacial water pressure on the sliding velocity of a glacier in an idealized numerical model', Journal of Glaciology 27(97), 407-421.

Iverson, N. R., McCracken, R. G., Zoet, L. K., Benediktsson, Í. Ö., Schomacker, A., Johnson, M. D. \& Woodard, J. (2017), 'A theoretical model of drumlin formation based on observations at Múlajökull, Iceland', Journal of Geophysical Research: Earth Surface 122, 2302-2323.

Jaeger, J. C., Cook, N. G. W. \& Zimmerman, R. W. (2007), Fundamentals of rock mechanics, Blackwell.

Johnson, M. D., Schomacker, A., Benediktsson, Í. Ö., Geiger, A. J., Ferguson, A. \& Ingólfsson, Ó. (2010), 'Active drumlin field revealed at the margin of Múlajökull, Iceland: a surge-type glacier', Geology 38(10), 943 - 946. 
Jónsson, S. A., Schomacker, A., Benediktsson, Í. Ö., Ingólfsson, Ó. \& Johnson, M. D. (2014), 'The drumlin field and the geomorphology of the Múlajökull surge-type glacier, central Iceland', Geomorphology 207, 213 - 220.

King, E., Hindmarsh, R. \& Stokes, C. (2009), 'Formation of mega-scale glacial lineations observed beneath a West Antarctic ice stream', Nature Geoscience 2, 585 - 588 .

Kleman, J., Hăttestrand, C., Borgstrôm, I. \& Stoeven, A. (1997), 'Fennoscandian palaeoglaciology reconstructed using a glacial geological inversion model', Journal of Glaciology 43(144), 283-299.

Lamsters, K., Karuš, J., Rečs, A. \& Bērzin̄̌s, D. (2016), 'Detailed subglacial topography and drumlins at the marginal zone of Múlajökull outlet glacier, central Iceland, evidence from low frequency gpr', Polar Science 10, 470-475.

Lawson, W. J., Sharp, M. J. \& Hambrey, M. J. (1994), 'The structural geology of a surge-type glacier', Journal of Structural Geology 16(10), 1447-1462.

Lovell, H., Fleming, E. J., Benn, D. I., Hubbard, B., Lukas, S. \& Naegeli, K. (2015), 'Former dynamic behaviour of a cold-based valley glacier on Svalbard revealed by basal ice and structural glaciology investigations', Journal of Glaciology 61(226), 309-328.

McCracken, R. G., Iverson, N. R., Benediktsson, Í. Ö., Schomacker, A., Zoet, L. K., Johnson, M. D., Hooyer, T. S. \& Ingólfsson, Ó. (2016), 'Origin of the active drumlin field at Múlajökull, Iceland: New insights from till shear and consolidation patterns', Quaternary Science Reviews 148, 243 - 260.

Moore, P. L., Iverson, N. R. \& Cohen, D. (2010), 'Conditions for thrust faulting in a glacier', Journal of Geophysical Research: Earth Surface 115, F02005.

Murray, T. \& Booth, A. D. (2010), 'Imaging glacial sediment inclusions in 3-D using ground-penetrating radar at Kongsvegen, Svalbard', Journal of Quaternary Science 25(5), 754-761. 
Murray, T., Gooch, D. L. \& Stuart, G. W. (1997), 'Structures within the surge front at Bakaninbreen, Svalbard, using ground-penetrating radar', Annals of Glaciology 24, 122 $-129$

Phillips, E., Everest, J., Evans, D. J., Finlayson, A., Ewertowski, M., Guild, A. \& Jones, L. (2017), 'Concentrated, 'pulsed' axial glacier flow: structural glaciological evidence from Kviarjokull in SE Iceland', Earth Surface Processes and Landforms 42, 1901-1922.

Phillips, E., Finlayson, A., Bradwell, T., Everest, J. \& Jones, L. (2014), 'Structural evolution triggers a dynamic reduction in active glacier length during rapid retreat: Evidence from Falljökull, SE Iceland', Journal of Geophysical Research: Earth Surface 119(10), 2194-2208.

Phillips, E., Finlayson, A. \& Jones, L. (2013), 'Fracturing, block faulting, and moulin development associated with progressive collapse and retreat of a maritime glacier: Falljökull, SE Iceland', Journal of Geophysical Research: Earth Surface 118(3), 15451561.

Rea, B. R. \& Evans, D. J. A. (2011), 'An assessment of surge-induced crevassing and the formation of crevasse squeeze ridges', Journal of Geophysical Research: Earth Surface 116, F04005.

Rose, J. (1987), Drumlins as part of a glacier bedform continuum., in J. Menzies \& J. Rose, eds, 'Drumlin Symposium', Balkema, Rotterdam, pp. 103-116.

Schulson, E. M. (2001), 'Brittle failure of ice', Engineering Fracture Mechanics 68, 18391887.

Sensors \& Software (2003), PulseEKKO PRO user's guide, Sensors and Software Inc., Mississauga, Canada.

Sharp, M., Lawson, W. \& Anderson, R. S. (1988), 'Tectonic processes in a surge-type glacier', Journal of Structural Geology 10(5), 499-515. 
Smith, A., Murray, T., Nicholls, K., Makinson, K., Adalgeirsdóttir, G., Behar, A. \& Vaughan, D. (2007), 'Rapid erosion, drumlin formation, and changing hydrology beneath an Antarctic ice stream', Geology 35(2), 127-130.

Spagnolo, M., Clark, C. D. \& Hughes, A. L. (2012), 'Drumlin relief', Geomorphology 153-154, 179-191.

Stokes, C. R. \& Clark, C. D. (2002), 'Are long subglacial bedforms indicative of fast ice flow?', Boreas 31(3), 239-249.

Stokes, C. R., Spagnolo, M. \& Clark, C. D. (2011), 'The composition and internal structure of drumlins: complexity, commonality, and implications for a unifying theory of their formation', Earth-Science Reviews 107(3-4), 398-422.

Tchalenko, J. S. (1968), 'The evolution of kink-bands and the development of compression textures in sheared clays', Tectonophysics 6, 159-174.

Woodward, J. \& Burke, M. J. (2007), 'Applications of ground-penetrating radar to glacial and frozen materials', Journal of Environmental \& Engineering Geophysics 12(1), 6985.

Woodward, J., Murray, T., Clark, R. A. \& Stuart, G. W. (2003), 'Glacier surge mechanisms inferred from ground-penetrating radar: Kongsvegen, Svalbard', Journal of Glaciology 49(167), $473-480$.

Woodward, J., Murray, T. \& McCaig, A. (2002), 'Formation and reorientation of structure in the surge-type glacier kongsvegen, svalbard', Journal of Quaternary Science $\mathbf{1 7}(3), 201-209$. 


\section{List of figures}

FIGURE 1. Photograph looking north-west towards Múlajökull, with the central margin and northern margin survey areas shown by the red boundaries. Photograph by Sverrir A. Jónsson, July 2011. Inset: Red square shows the location of Múlajökull and the Hofsjökull ice cap in central Iceland. Hillshade image based on data from the National Land Survey of Iceland.

FIGURE 2. A. Position of survey lines (white lines), and the outlines (black polygons) of the central and northern margin areas of the glacier where the bed topography was interpolated. B. Ice thickness determined from the GPR bed reflector picks is shown for the survey lines. Inset images show spacing of the GPR survey tracks. C-D. Examples of the continuous, high amplitude basal reflectors. (C) Profile 005 parallel to ice flow. (D) Profile 86 transverse to ice flow. The basal reflector in $\mathrm{C}$ is clearly traced to the exposed glacier bed. Ice flow direction in $\mathrm{D}$ is out of the page.

FIGURE 3. Glacier bed interpolations (blue-red colour ramp) for (A) the central margin study area and (B) the northern margin study area.

FIGURE 4. Examples of (A) near surface and englacial hyperbolas in an unmigrated transverse profile, (B) a continuous subhorizontal reflector in a transverse profile, (C) a dipping reflector plane captured in two intersecting profiles, (D) up-glacier dipping englacial reflectors, and (E) down-glacier dipping englacial reflectors, identified in the GPR surveys.

FIGURE 5. Up-glacier dipping (red) and down-glacier dipping (blue) reflectors projected over the interpolated subglacial topography, and rose plots showing the bedslope direction immediately beneath the reflectors. (A-C) central margin, (D-F) northern mar- 
gin. The individual lines of points in (A) and (D) each represent a reflector surface that was traced for a distance normal to the glacier margin.

FIGURE 6. Histograms show the depth of all up-glacier dipping (red) and downglacier dipping (blue) reflector segments, and rose plots showing apparent dip angles for the reflector segments. (A-C) central margin, (D-F) northern margin.

FIGURE 7. Slope of the glacier bed as a whole, and under each of the sets of reflectors, for (A) the central margin and (B) the northern margin.

FIGURE 8. Transverse fractures on the glacier surface in front of an exposed swale. B. Up-glacier dipping fracture exposed in the side wall of a longitudinal crevasse. Person for scale. C. Deformed silty sand within an up-ice dipping fracture indicating compression. D. Lower hemisphere stereographic plot of fracture planes for all sediment filled fractures measured in the central glacier margin.

FIGURE 9. A. Hill-shaded elevation model generated from UAV survey. The GPR profile 66 crosses at least two sets of transverse fractures, and associated sediment ridges, close to the glacier margin in front of an emerging inter drumlin swale. B. GPR profile showing that the transverse surface fractures are part of up-glacier dipping fracture planes that connect to the glacier bed. The elevation profile obtained from the UAV survey is also shown indicating the position of the sediment ridges.

FIGURE 10. A-D. Up-glacier and down-glacier dipping fractures and faults mapped in sections along two longitudinal crevasses at the central margin site. A. Fractures and foliation shown in the upper part of a $130 \mathrm{~m}$ long crevasse section. B-C Photograph and interpretation showing a fracture offsetting and interpreted inclined anticline at approximately $20 \mathrm{~m}$ in (A). D. Fractures and foliation shown in the upper part of a $290 \mathrm{~m}$ long 
703

704

707

crevasse section.

FIGURE 11. A: Pressurised water emerging from a fracture system at the glacier surface. This system could be traced as a down-glacier dipping fracture that connects to the glacier bed.

FIGURE 12. A. Conceptual diagram illustrating the relationship between fractures and the bed topography. B. Horizontal view of mapped sediment-filled fractures in the northern margin plotted over the glacier bed. 


\begin{tabular}{lllll}
\hline Reflector length & \multicolumn{2}{c}{ Central margin } & \multicolumn{2}{c}{ Northern margin } \\
\cline { 2 - 5 } & $\begin{array}{l}\text { Up-glacier } \\
\text { dipping } \\
(\mathrm{n}=105)\end{array}$ & $\begin{array}{l}\text { Down- } \\
\text { glacier } \\
\text { dipping } \\
(\mathrm{n}=52)\end{array}$ & $\begin{array}{l}\text { Up-glacier } \\
\text { dipping } \\
(\mathrm{n}=34)\end{array}$ & $\begin{array}{l}\text { Down- } \\
\text { glacier } \\
\text { dipping } \\
(\mathrm{n}=40)\end{array}$ \\
\hline Maximum (m) & 18 & 44 & 24 & 68 \\
Minimum (m) & 2 & 2 & 4 & 6 \\
Mean (m) & 8.8 & 15.1 & 10.2 & 23.5 \\
Median (m) & 6 & 14 & 10 & 20 \\
\hline
\end{tabular}

Table 1: Horizontal flow-parallel distances over which reflectors were traced. 


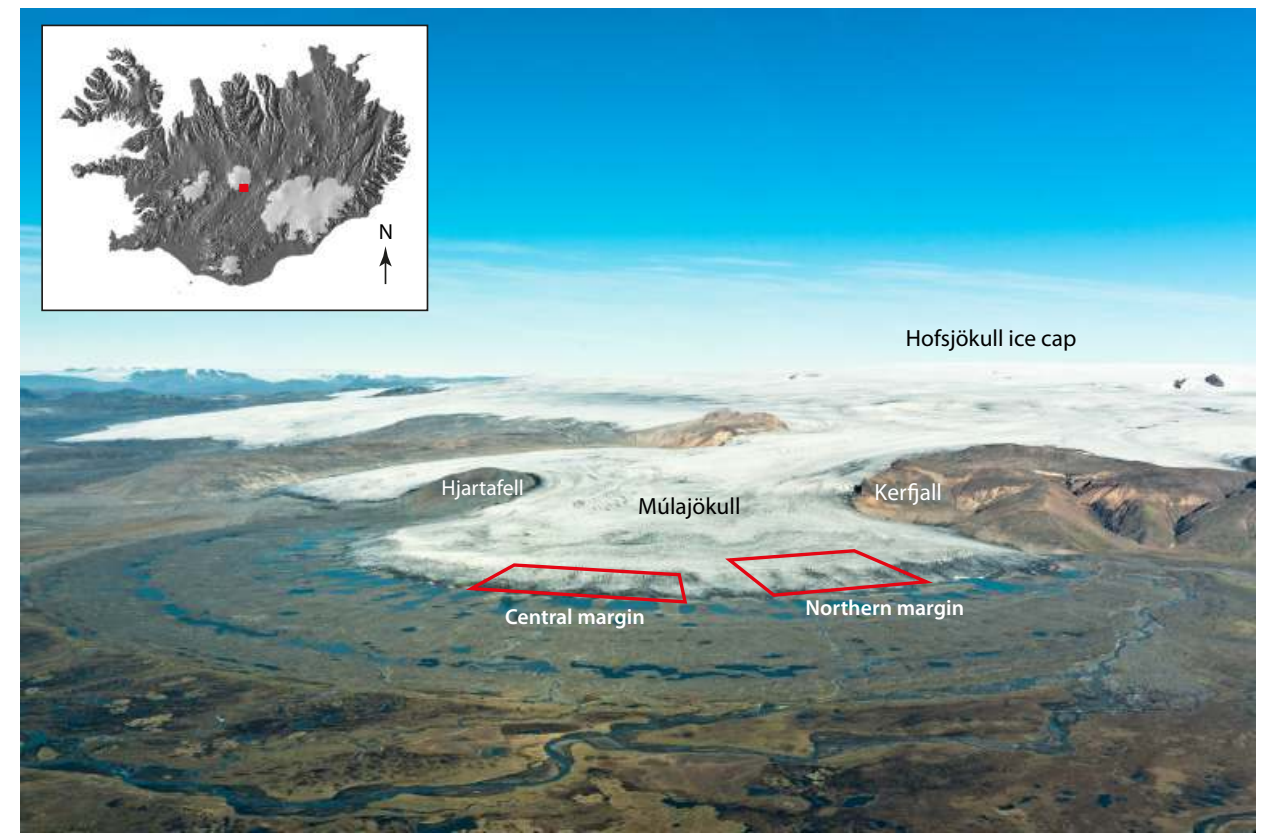

Figure 1: Photograph looking north-west towards Múlajökull, with the central margin and northern margin survey areas shown by the red boundaries. Photograph by Sverrir A. Jónsson, July 2011. Inset: Red square shows the location of Múlajökull and the Hofsjökull ice cap in central Iceland. Hillshade image based on data from the National Land Survey of Iceland. 

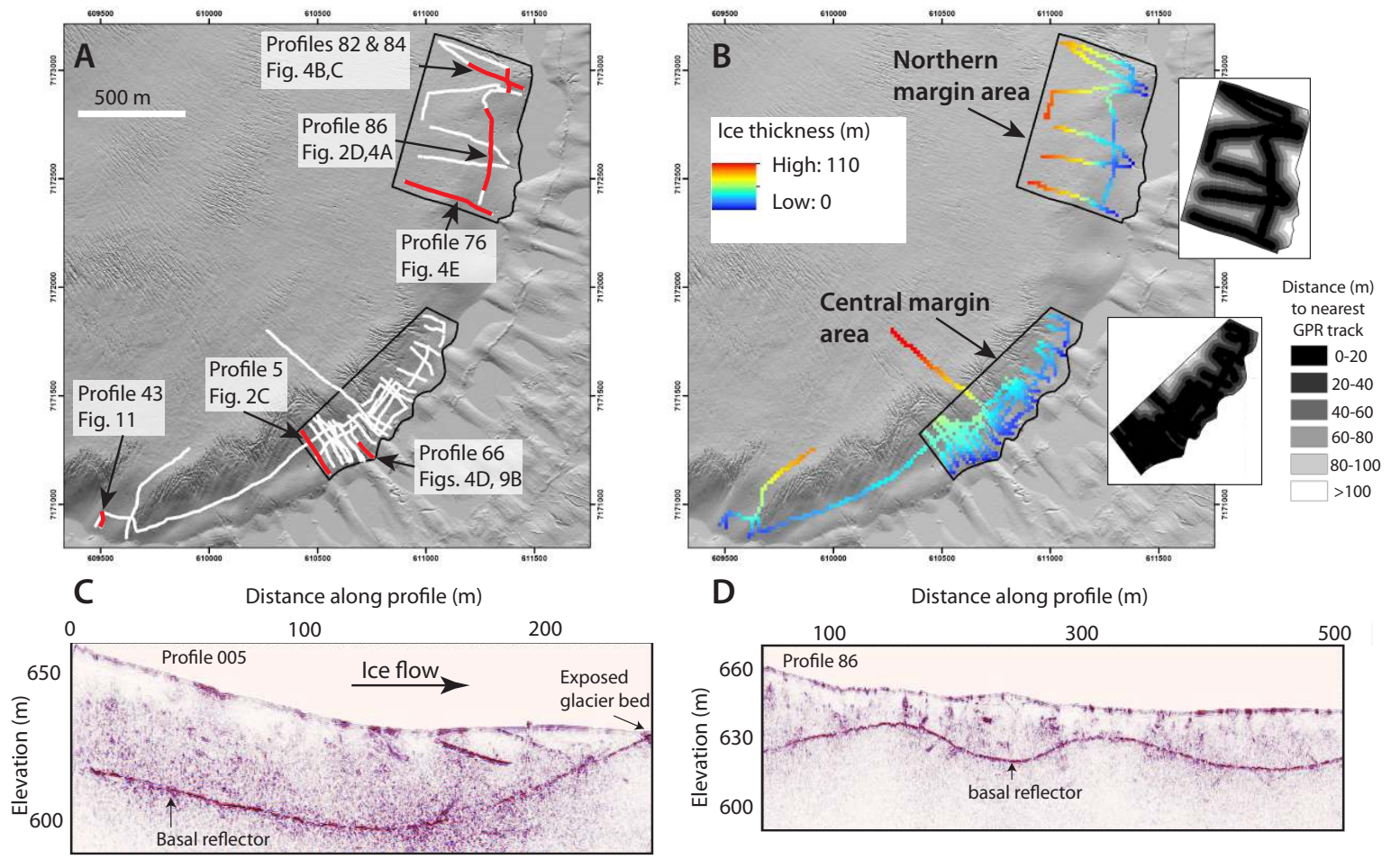

Figure 2: A. Position of survey lines (white lines), and the outlines (black polygons) of the central and northern margin areas of the glacier where the bed topography was interpolated. B. Ice thickness determined from the GPR bed reflector picks is shown for the survey lines. Inset images show spacing of the GPR survey tracks. C-D. Examples of the continuous, high amplitude basal reflectors. (C) Profile 005 parallel to ice flow. (D) Profile 86 transverse to ice flow. The basal reflector in $\mathrm{C}$ is clearly traced to the exposed glacier bed. Ice flow direction in $\mathrm{D}$ is out of the page. 

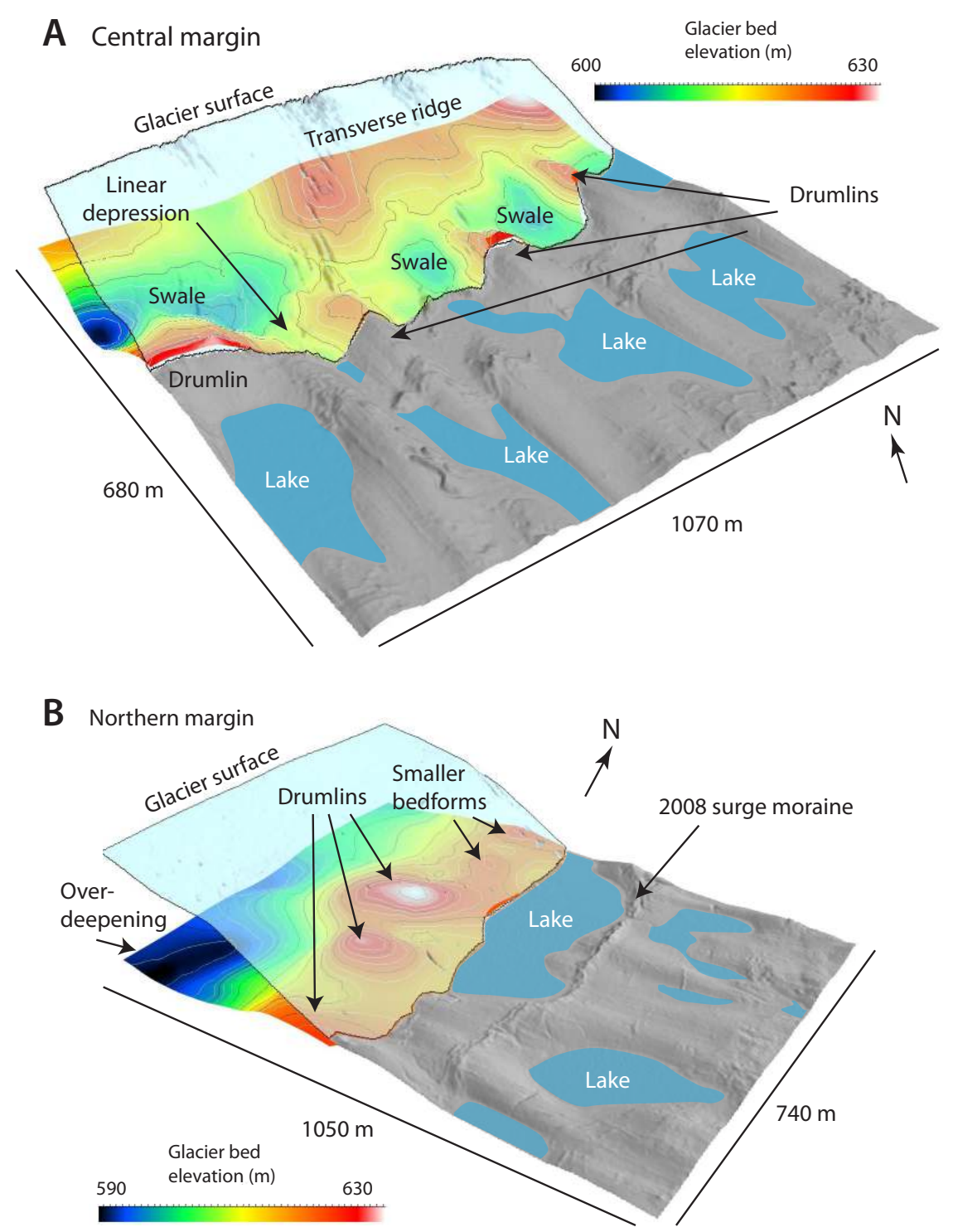

Figure 3: Glacier bed interpolations (blue-red colour ramp) for (A) the central margin study area and (B) the northern margin study area. 

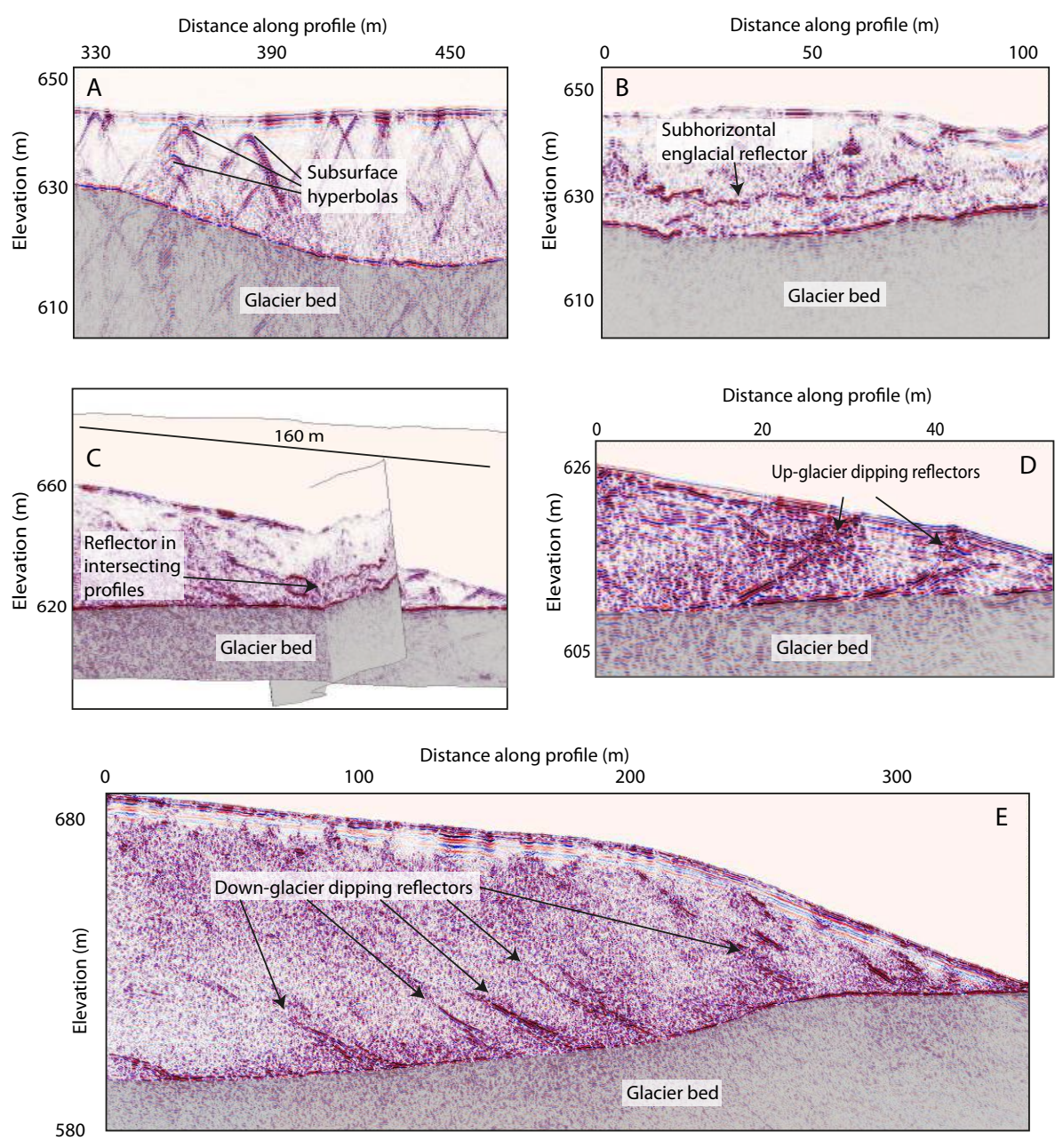

Figure 4: Examples of (A) near surface and englacial hyperbolas in an unmigrated transverse profile, (B) a continuous subhorizontal reflector in a transverse profile, (C) a dipping reflector plane captured in two intersecting profiles, (D) up-glacier dipping englacial reflectors, and (E) down-glacier dipping englacial reflectors, identified in the GPR surveys. 


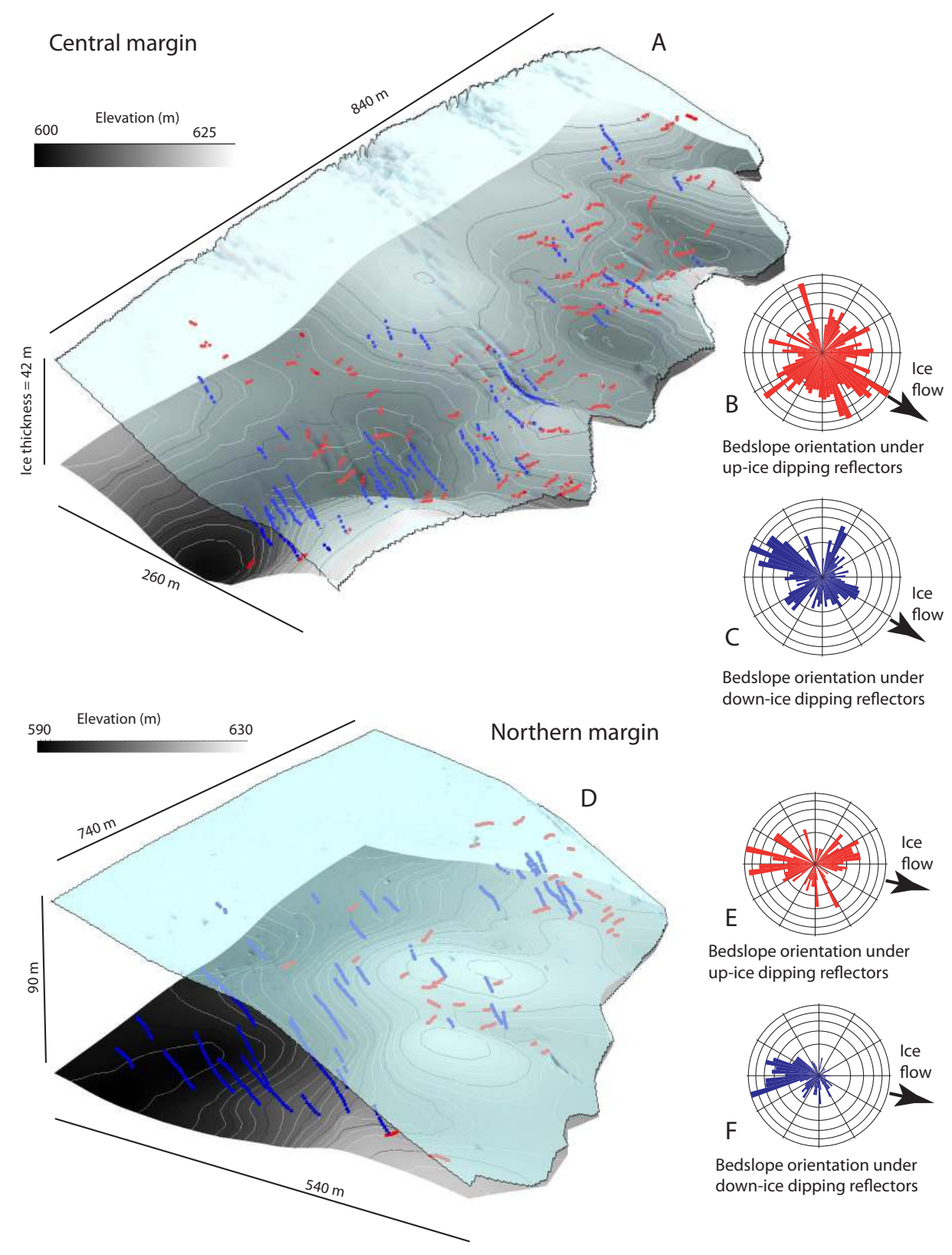

Figure 5: Up-glacier dipping (red) and down-glacier dipping (blue) reflectors projected over the interpolated subglacial topography, and rose plots showing the bedslope direction immediately beneath the reflectors. (A-C) central margin, (D-F) northern margin. The individual lines of points in (A) and (D) each represent a reflector surface that was traced for a distance normal to the glacier margin. 

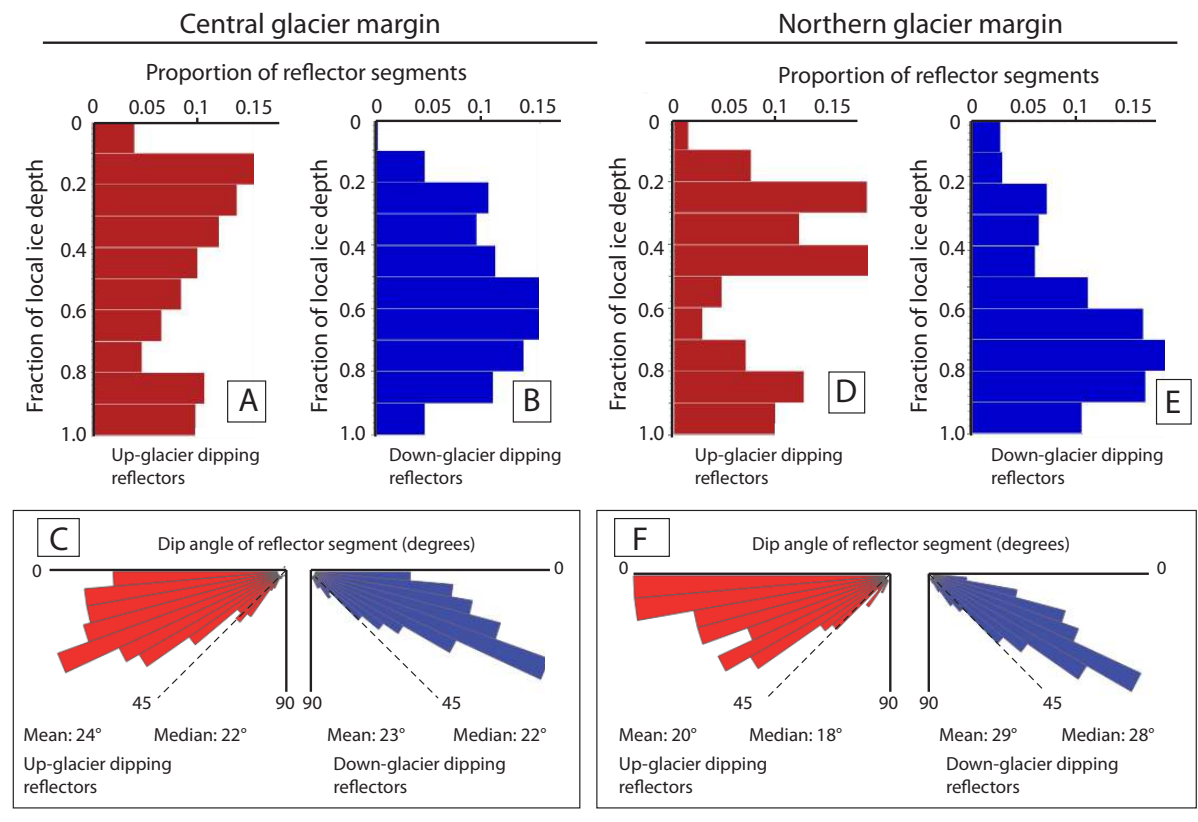

Figure 6: Histograms show the depth of all up-glacier dipping (red) and down-glacier dipping (blue) reflector segments, and rose plots showing apparent dip angles for the reflector segments. (A-C) central margin, (D-F) northern margin.
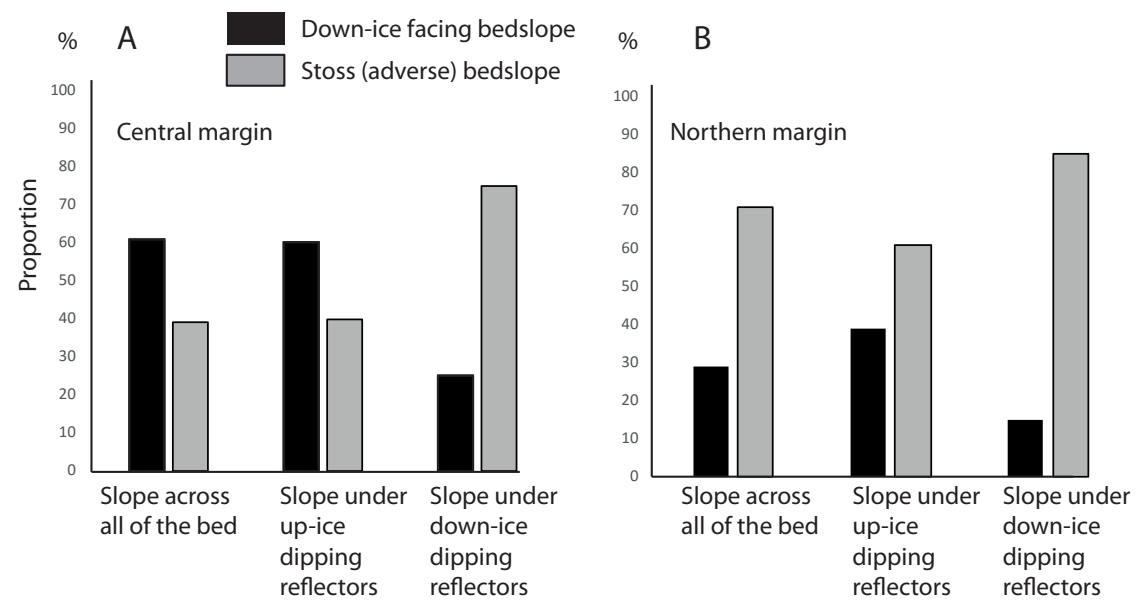

Figure 7: Slope of the glacier bed as a whole, and under each of the sets of reflectors, for (A) the central margin and (B) the northern margin. 

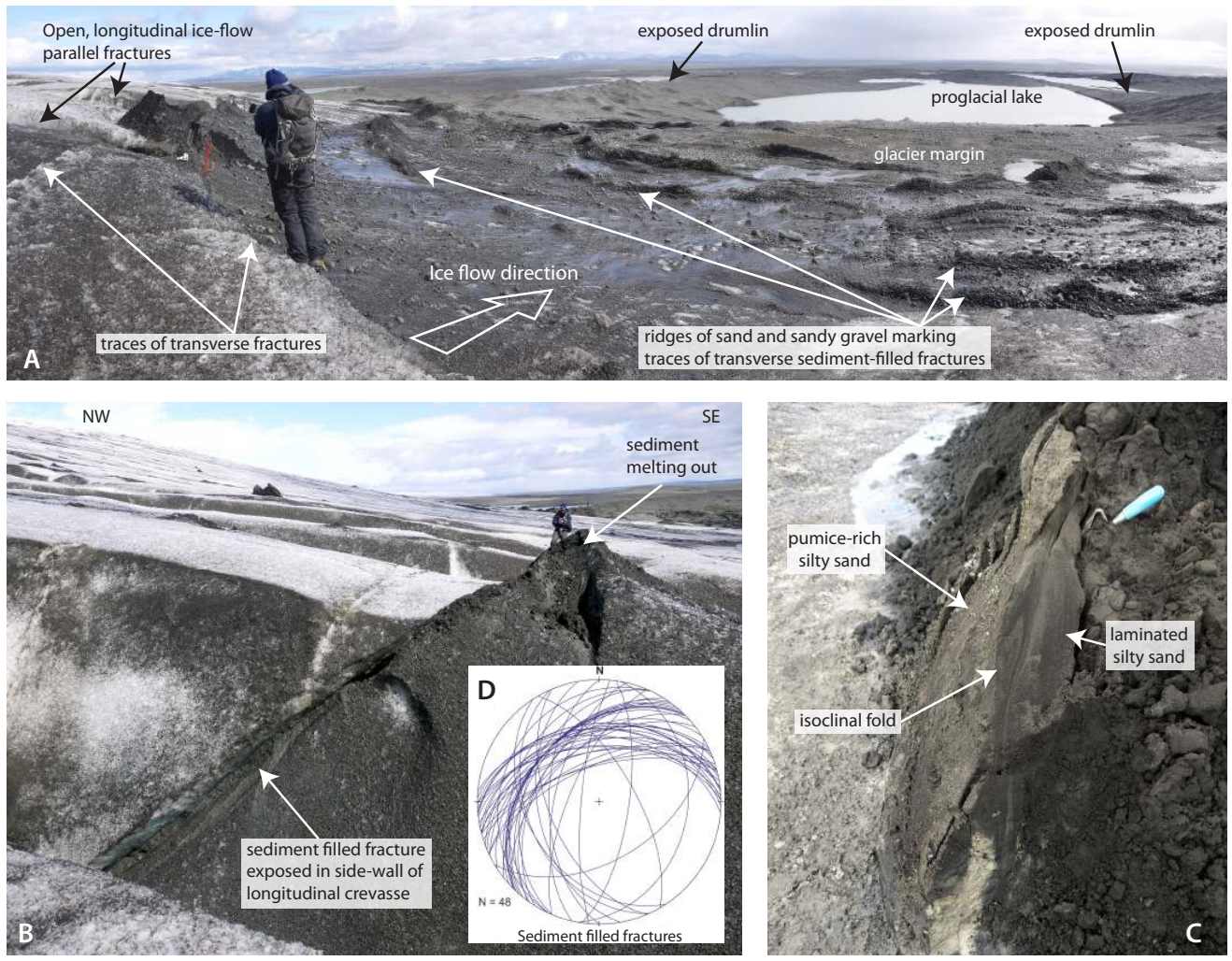

Figure 8: Transverse fractures on the glacier surface in front of an exposed swale. B. Up-glacier dipping fracture exposed in the side wall of a longitudinal crevasse. Person for scale. C. Deformed silty sand within an up-ice dipping fracture indicating compression. D. Lower hemisphere stereographic plot of fracture planes for all sediment filled fractures measured in the central glacier margin. 


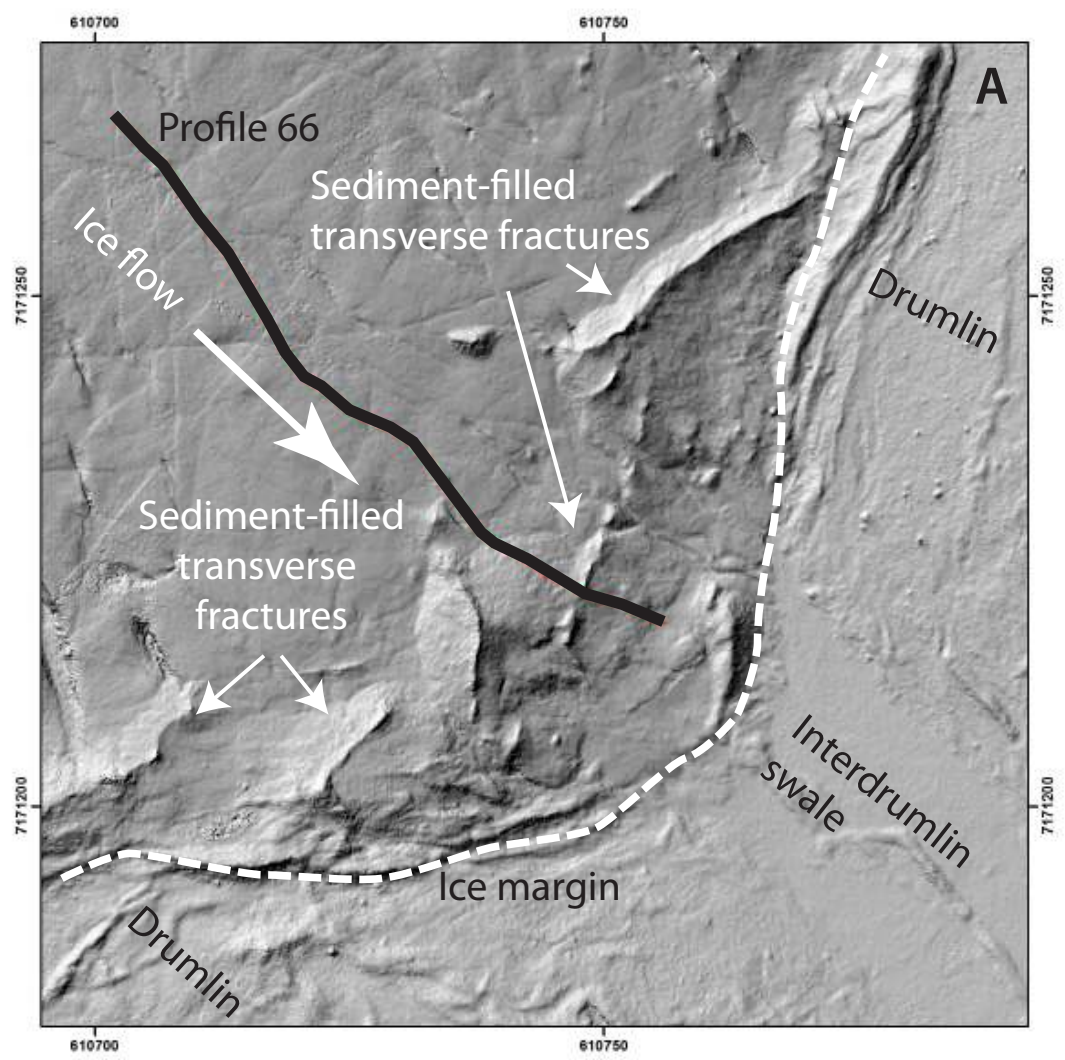

B

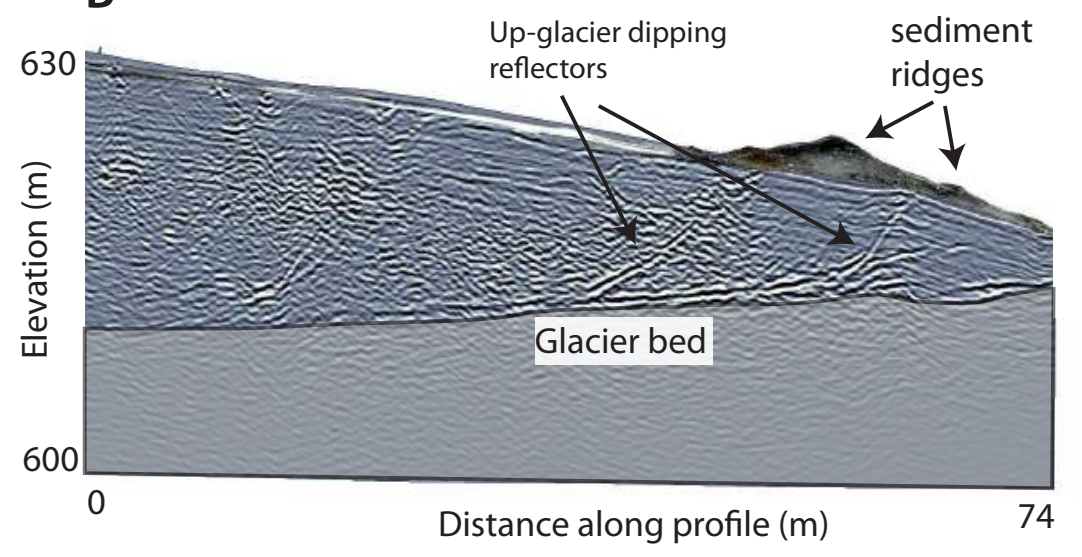

Figure 9: A. Hill-shaded elevation model generated from UAV survey. The GPR profile 66 crosses at least two sets of transverse fractures, and associated sediment ridges, close to the glacier margin in front of an emerging inter drumlin swale. B. GPR profile showing that the transverse surface fractures are part of up-glacier dipping fracture planes that connect to the glacier bed. The elevation profile obtained from the UAV survey is also shown indicating the position of the sediment ridges. 

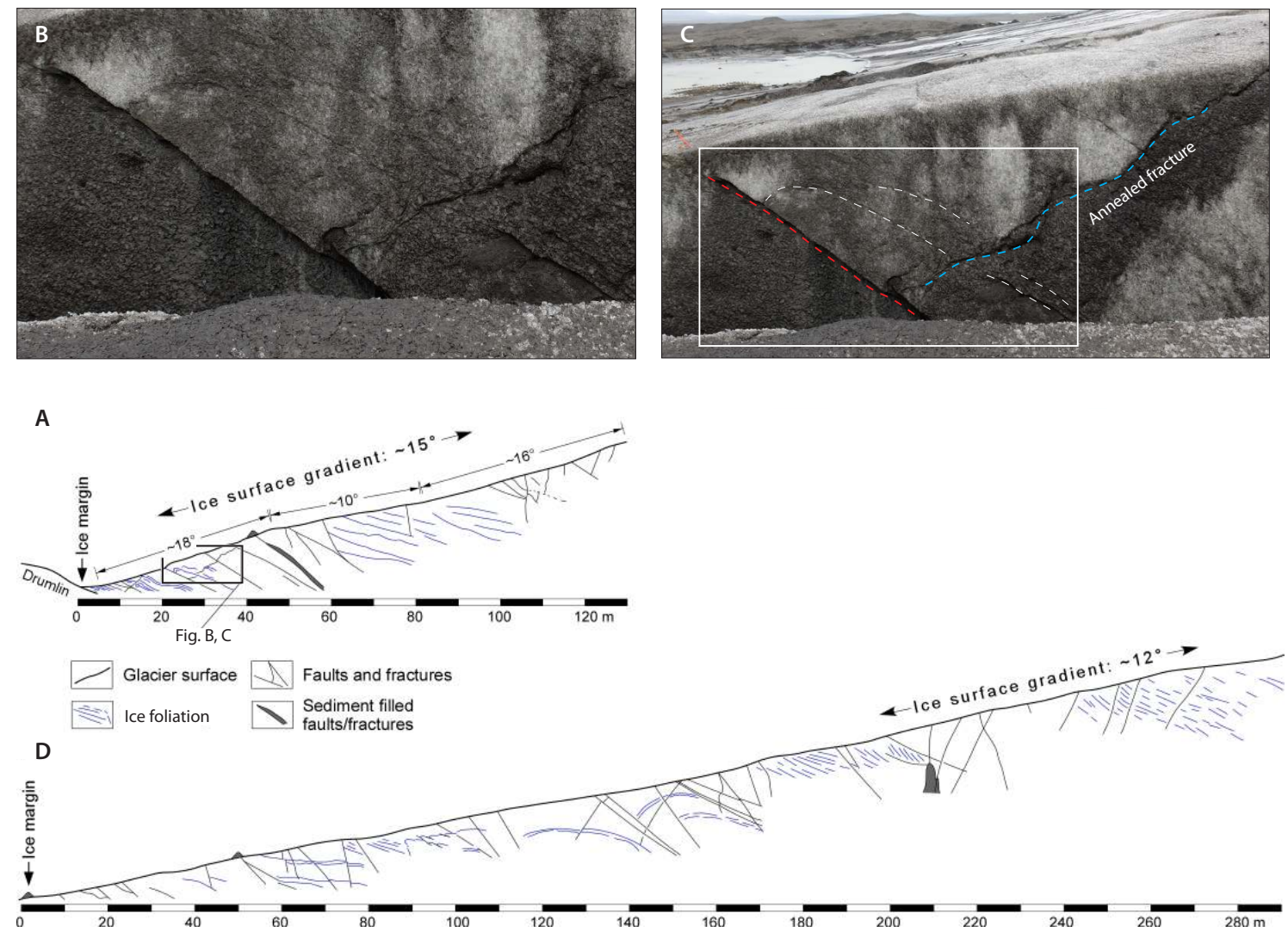

Figure 10: A-D. Up-glacier and down-glacier dipping fractures and faults mapped in sections along two longitudinal crevasses at the central margin site. A. Fractures and foliation shown in the upper part of a $130 \mathrm{~m}$ long crevasse section. B-C Photograph and interpretation showing a fracture offsetting and interpreted inclined anticline at approximately $20 \mathrm{~m}$ in (A). D. Fractures and foliation shown in the upper part of a $290 \mathrm{~m}$ long crevasse section. 


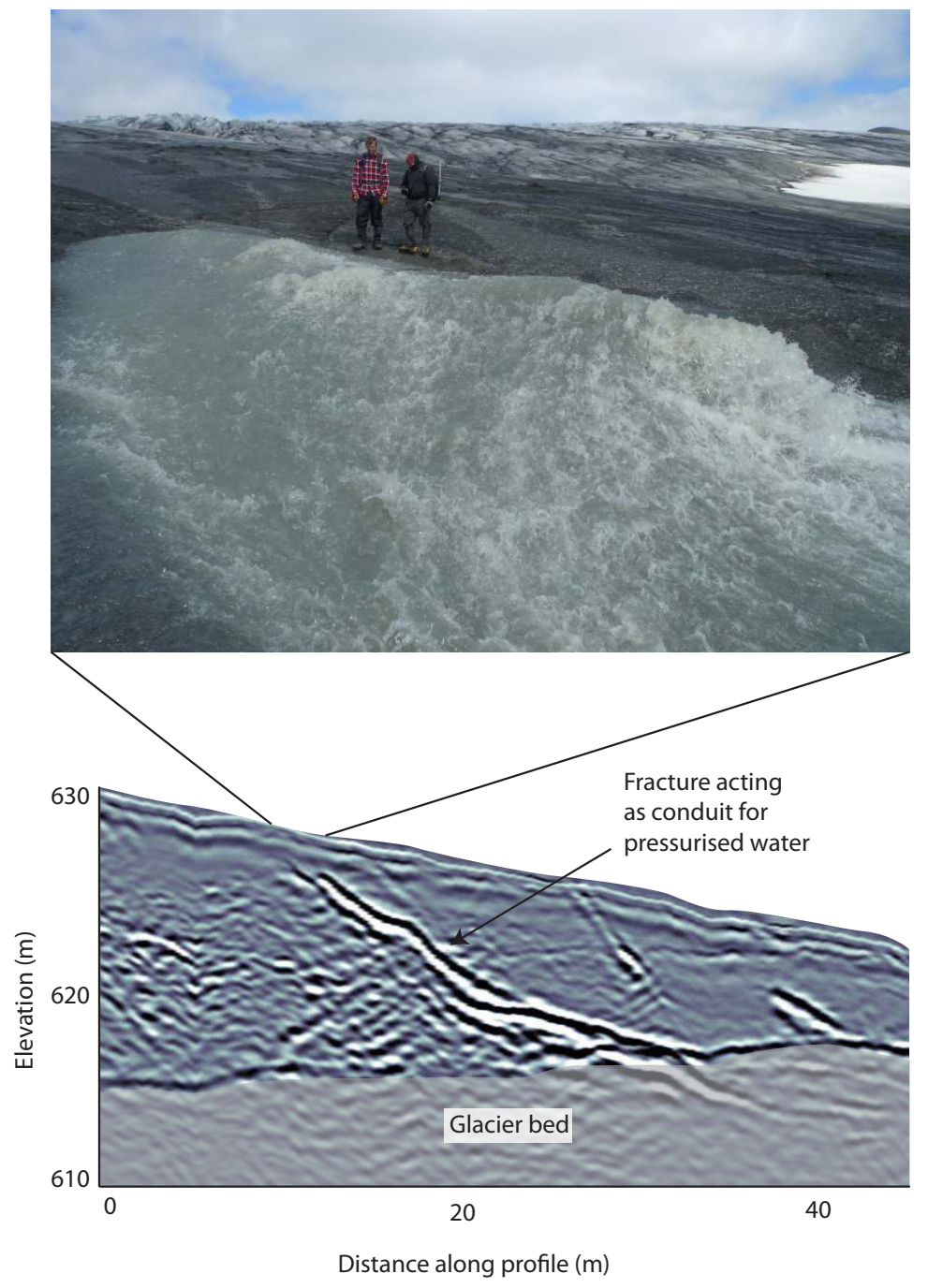

Figure 11: A: Pressurised water emerging from a fracture system at the glacier surface. This system could be traced as a down-glacier dipping fracture that connects to the glacier bed. 


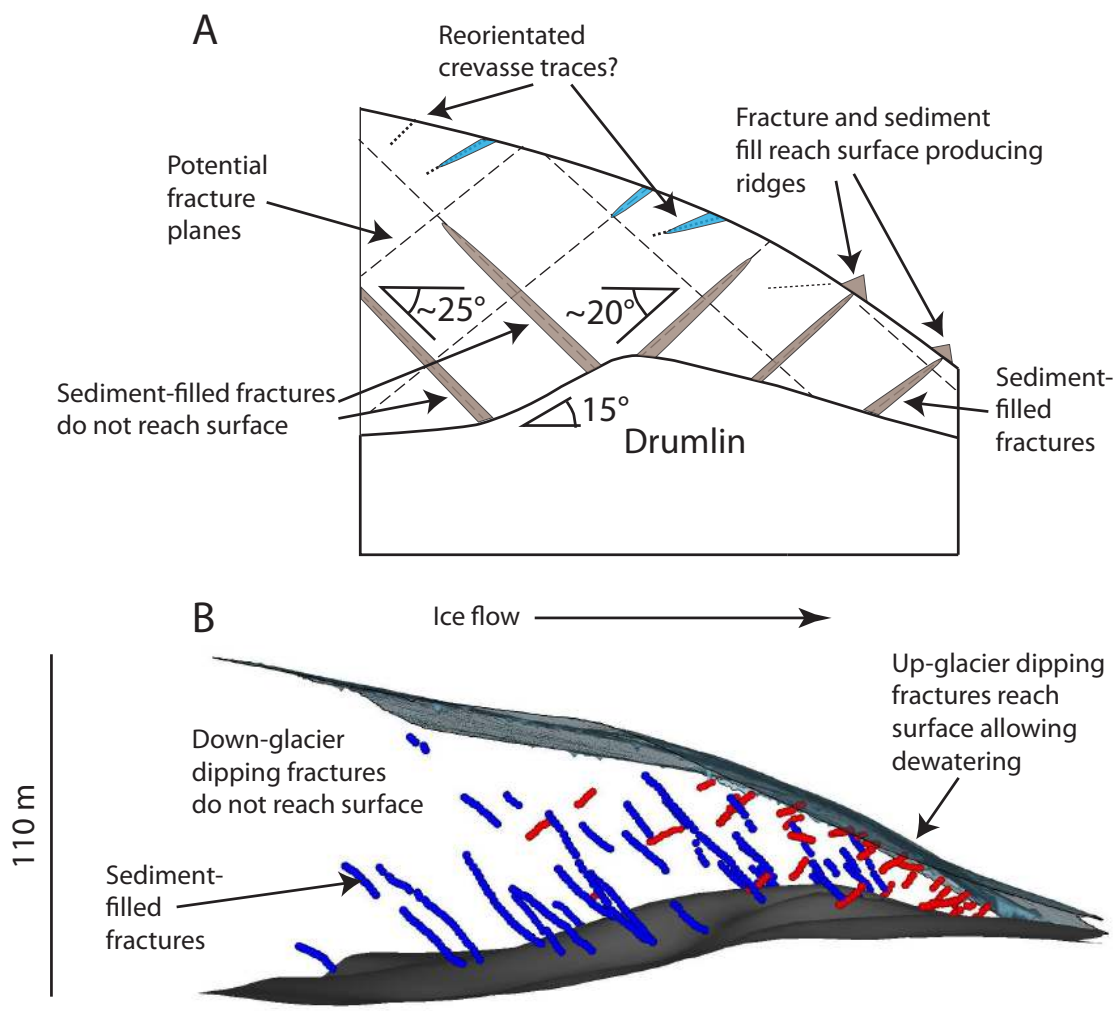

$550 \mathrm{~m}$

Figure 12: A. Conceptual diagram illustrating the relationship between fractures and the bed topography. B. Horizontal view of mapped sediment-filled fractures in the northern margin plotted over the glacier bed. 